\title{
KEUTAMAAN AKHLAK DALAM PEMBANGUNAN KEUSAHAWANAN ISLAM
}

\section{Centrality of $\boldsymbol{A k h l a ̄ q}$ in Islamic Entrepreneurship Development}

\author{
Solahuddin Abdul Hamid ${ }^{1}$ \\ Che Zarrina Sa'ari² \\ Mohd.Akram Dato' Dahaman@Dahlan ${ }^{3}$
}

\begin{abstract}
The entrepreneurial spirit is universal and transcends racial, cultural, and geographical limitations. However, this spirit is qualified further when fostered by Muslim entrepreneurs. When a career is associated with Islam, behavior needs to be managed in a holistic manner according to Islamic guidelines. Generally, the Islamic perspective encourages entrepreneurship. The only difference is that the fundamentals the religion should serve as the cornerstone of all entrepreneurial activity. This article will explain the element of akhlāq (moral practice) as one of the main
\end{abstract}

1 Senior Lecturer, Centre for General Studies, College of Arts and Sciences, Universiti Utara Malaysia, 06010 Sintok, Kedah, solah@uum.edu.my

2 Associate Professor, Department of Aqidah and Islamic Thought, Academy of Islamic Studies, University of Malaya, 50603 Kuala Lumpur, zarrina@um.edu. my.

3 Senior Lecturer, Centre for General Studies, College of Arts and Sciences, Universiti Utara Malaysia, 06010 Sintok, Kedah, akram@uum.edu.my 
components in the development of the entrepreneur's personality through the appreciation of Islam as found in al-Qur'ān, ahādìth, and by scholars of Islam.

Keywords: akhlāq, personality, entrepreneur, Islam, al-Qur'ān, al-Hadīth

\section{PENDAHULUAN}

Secara akademiknya, Islam mempunyai tiga cabang utama iaitu akidah sebagai teras pegangan hidup, Syariah menyusun amalan hidup yang mencorakkan tingkah laku serta akhlak sebagai etika hidup manifestasi daripada akidah yang jelas dan Syariah yang mantap. Ketiga-tiga komponen ini seharusnya bergerak secara bersepadu tanpa sebarang pemisahan bagi melahirkan umat Islam yang terbaik sebagaimana yang telah dinyatakan oleh Allah SWT dalam alQuran. Memandangkan kerjaya sebagai usahawan sentiasa berhubung dengan masyarakat, penuh dengan persaingan, tipu muslihat dan berisiko, maka elemen akhlak mendapat keutamaan selari dengan pembangunan usahawan. Menjadikan akidah sebagai dasar, Syariah sebagai panduan dan akhlak sebagai etika dalam aktiviti keusahawanan tidak menafikan matlamat keuntungan, tetapi kaedah mendapatkannya tidak mengatasi matlamat yang lebih utama iaitu mendapatkan keredaan Allah SWT, mewujudkan kesatuan sosial, saling cinta-mencintai, kasih sayang, keharmonian sosial dan persaudaraan.

\section{Ulasan Karya}

Manusia adalah makhluk dualistik yang memikul dua tanggungjawab besar untuk mengimbangi tujuan kehidupannya supaya tidak terjerumus ke dalam asetisisme mutlak atau materialisme sepenuhnya. Sebagai khalifah ${ }^{4}$ manusia berhak menggunakan kekuatan akal dan fizikalnya untuk membangun dan memajukan alam hingga ke peringkat semaksima mungkin manakala sebagai hamba, ${ }^{5}$ kebebasan bertindak adalah terhad dan tertakluk kepada sempadan dan garis panduan yang telah ditetapkan oleh Allah SWT. Pemilik harta yang mutlak adalah Allah SWT, ${ }^{6}$ manakala kapasiti manusia hanya sekadar

4 Surah al-Baqarah (2): 30 yang bermaksud: "Dan (ingatlah) ketika Tuhanmu berfirman kepada Mala'ikat: "Sesungguhnya Aku hendak menjadikan seorang khalifah di bumi".

5 Surah al-Dhāriyāt(51): 56 yang bermaksud: "Dan (ingatlah) Aku tidak menciptakan jin dan manusia melainkan untuk mereka menyembah dan beribadat kepadaKu"

6 Surah al-Baqarah (2): 22 yang bermaksud: "Dialah yang menjadikan bumi ini untuk kamu sebagai hamparan, dan langit (serta segala isinya) sebagai bangunan (yang dibina dengan kukuhnya); dan diturunkannya air hujan dari langit, lalu dikeluarkannya dengan air itu berjenis-jenis buah-buahan yang menjadi rezeki bagi kamu". 
pemegang amanah ${ }^{7}$ (مستخلفين فيه) yang perlu berusaha berdasarkan batas kemampuan tertentu untuk mendapatkannya, manakala penggunaannya pula merupakan satu ujian bagi mereka. ${ }^{8}$ Implikasi daripada taraf tersebut, manusia perlu tunduk dan beriman kepada Allah SWT yang Maha Berkuasa dalam mencipta dan menurunkan bantuan tersebut tanpa mengira lemah atau kuatnya mereka bekerja. ${ }^{9}$

\section{KEUSAHAWANAN DALAM ISLAM}

Keusahawanan telah digunakan secara meluas di dalam al-Quran apabila tema komersil ini telah diulang sebanyak 370 kali melalui 20 jenis terminologi yang berbeza. Kekerapan pengulangan tema ini menggambarkan bahawa adanya satu manifestasi semangat yang bersifat komersil dalam tasawwur Islam. ${ }^{10}$ Terminologi al-bay' (البيع) dalam al-Quran adalah berbentuk umum serta merujuk kepada pelbagai jenis aktiviti yang boleh mendatangkan keuntungan seperti urusniaga, perniagaan dan industri. ${ }^{11}$ Dalam erti kata lain, al-bay

$7 \quad$ Lihat surah al-Hadīd (57): 7.

8 Individu yang melihat harta dari sudut pandangan peribadi akan menganggap kejayaan beliau mengumpul dan mengembangkan harta tersebut adalah melalui usahanya semata-mata. Oleh itu, hanya dia seorang sahaja yang berhak untuk menikmati hasilnya. Sebaliknya, individu yang melihat dirinya sebagai khalifah Allah SWT akan mengakui harta pada realitinya adalah milik Allah SWT yang telah menciptakan bahan mentah dan menjadikannya bermanfaat kepada manusia dan seluruh makhluk. Analogi sifat-sifat ini telah digambarkan dengan jelas dalam al-Quran. Contohnya, Qarun dengan penuh kemegahan berkata yang bermaksud: "Sesungguh aku diberikan harta itu semata-mata kerana ilmu yang ada padaku” (Surah al-Qașāṣ, 28: 78). Sebaliknya Nabi Sulaymān AS dengan penuh kesyukuran atas nikmat Tuhannya berkata yang bermaksud: "Ini termasuk kurniaan Tuhanku untuk mencubaku sama ada aku bersyukur atau ingkar (akan nikmatNya). Dan sesiapa yang bersyukur sesungguhnya dia bersyukur untuk (kebaikan) dirinya sendiri dan sesiapa yang ingkar, maka sesungguhnya Tuhanku Maha Kaya lagi Maha Mulia” (Surah al-Naml, 27: 40). Keterangan lanjut, lihat Yūsuf al-Qarāḍāwī, Dawr al-Qiyām wa al-Akhlāq fí al-Iqtiṣād al-Islāmī (Qāhirah: Maktabah Wahbah, 2001).

9 Surah al-'Ankābūt (29): 62 yang bermaksud: “Allah memewahkan rezeki bagi sesiapa yang dikehendakiNya di antara hamba-hambaNya dan menyempitkan (rezeki itu) baginya, sesungguhnya Allah amat mengetahui akan tiap-tiap sesuatu".

10 Mustaq Ahmad, Business Ethics in Islam (Islamabad: International Institute of Islamic Thought, 1995).

11 Antara yang telah dinyatakan dalam al-Quran adalah seperti industri senjata, batubata, pembinaan, permaidani, tembikar, tembaga, perabut, kaca, emas, perak, besi, keluli, kulit, kasut, perlombongan, pembinaan kapal dan lain-lain. Lihat, Afzalur Rahman, Subject Index of Quran (Lahore: Islamic Publications, 1993). 
melibatkan aktiviti keusahawanan untuk mendapatkan keuntungan, bukannya dalam bentuk kerja yang bergaji.

Berdasarkan tasawwur Islam, kerjaya usahawan bukan sekadar mencari keuntungan ${ }^{12}$ untuk menyara keperluan hidup diri dan keluarga semata-mata. Malah, apa yang lebih penting usahawan menawarkan khidmat kebajikan kepada masyarakat dengan memenuhi keperluan mereka untuk mendapatkan barangan atau perkhidmatan yang diingini. ${ }^{13}$ Dalam erti kata lain, aktiviti ini bukan sekadar satu usaha untuk memperolehi keuntungan melalui penambahan modal dan usaha ${ }^{14}$ atau sebagai mekanisme pertukaran barangbarang keperluan, malah ia merupakan satu ibadah ${ }^{15}$ dalam usaha menawarkan khidmat sosial kepada masyarakat serta membina ketamadunan umat dan masa depannya. ${ }^{16}$

12 Saidina 'Ali pernah berkata: "Wahai peniaga, janganlah kamu menolak keuntungan yang sedikit dan mengharamkan yang banyak”. Bagaimanapun, tidak ada jawapan yang pasti tentang harga berpatutan dan keuntungan berpatutan. Ianya bergantung kepada masa dan keadaan. Menurut Isma'il Raji al-Faruqi menjelaskan, memperolehi keuntungan lumayan bukan suatu kesalahan jika ia tidak berasaskan tipu daya dan tidak membahayakan orang ramai. Pada prinsipnya, Islam menentang pengawalan harga, namun halangan tersebut lebih kepada ingin mengawal kenaikan harga yang berlebihan dan keuntungan lumayan yang tidak bermoral. Penetapan pengawalan harga atau gaji tidak digalakkan supaya peniaga tidak rugi. Ini kerana, setiap perniagaan mempunyai risiko yang berkemungkinan untung atau rugi. Manakala Muhammad Nejatullah Siddiqi (1992) mendefinisikan keuntungan yang memuaskan dengan merujuk kepada jumlah keuntungan di antara had tertinggi yang dibolehkan oleh keadaan dan had terendah yang membolehkan pengusaha dapat hidup dengan baik bagi menutupi kerugian. Dalam erti kata lain, ia dapat memuaskan perasaan pengusaha yang ingin berbakti dan juga berkeinginan memungut wang, memelihara dan mengembangkan perniagaannya, menjaga hubungan baik dengan pengguna, kerajaan dan orang ramai amnya. Lihat Isma'il Raji al-Faruqi, al-Tawhid: Its Implications for Thought and Life (Virginia, U.S.A.: International Institute of Islamic Thought, 1992), 179; Muhammad Nejatullah Siddiqi, The Economic Enterprise in Islam (Lahore: Islamic Publications Ltd. 2000), 107.

13 Muhammad Nejatullah Siddiqi, The Economic Enterprise in Islam, 103.

14 Ibn Khaldūn, Muqaddimah (Qāhirah: Dār al-Sha'b, t.t.), 355.

15 Sayyid Șābiq, Fiqh al-Sunnah, vol. 3 (Qāhirah: Dār al-Fatḥ li al-I'lām al-‘Arābī, 1994), 148.

16 Muhammad 'Abd al-Ḥalīm 'Amr, 'Mafhūm al-Intāj wa Darūrath wa Ahdāfīh', Majallah Markāz Șāliḥ Kāmil li al-Iqtiṣāẹ al-Islāmì Jamī'ah al-Azhār, 3/8 (1999): 90-91. 
Secara fitrahnya, kemampuan dan tenaga manusia adalah terhad sedangkan keinginan dan keperluan mereka adalah pelbagai. Maka, melalui pelbagai kontrak jual beli sebagai wasilah yang diharuskan, pelbagai keinginan dan keperluan tersebut dapat dipenuhi berdasarkan kemampuan yang dimiliki. Muhammad al-Mubārak menjelaskan, secara teorinya keusahawanan Islam tidak menjadikan pengeluaran dan keuntungan sebagai matlamat utama tetapi lebih berperanan sebagai alat kerana asas kuasa penggerak bagi sistem Islam ialah kebajikan manusia. ${ }^{17}$ Justeru, selain sebagai memenuhi keperluan hidup manusia, aktiviti keusahawanan juga adalah sebahagian daripada gambaran spiritual Islam yang bersifat holistik sama ada dalam bentuk teori atau praktikal.

\section{AKHLAK DALAM KEUSAHAWANAN ISLAM}

Objektif Syariat Islam ialah menghasilkan kebaikan dan menolak keburukan di dunia dan akhirat melalui tiga kategori yang utama iaitu kepentingan asas (al-darūriyyah), keperluan biasa (al-häjiyyah) dan keperluan kemewahan (al-tahsiniyyah). Pemenuhan keperluan atau pemilikan harta seharusnya mengutamakan al-ḍaūriyyah terlebih dahulu. Kemudian diikuti al-hājiyyah dan al-tahsiniyyah. Al-Darūriyyah merujuk kepada keperluan asasi yang perlu dipenuhi oleh manusia sama ada untuk tujuan hidup di dunia atau akhirat. Terdapat lima perkara asas iaitu iman yang berkaitan dengan agama (al-dìn), nyawa yang berkaitan dengan kehidupan (al-nafs), akal (al-'aql), keturunan (al-nasl) dan harta (al-mal) yang berkaitan dengan kesempurnaan akhlak manusia. Kehidupan manusia akan menjadi rosak atau terganggu jika keperluan ini tidak dipenuhi.

Al-Häjiyyah pula lebih kepada memudahkan supaya kehidupan di dunia dan akhirat menjadi lebih sempurna dan terurus. Manakala al-tahsininiyyah pula akan memperelokkan lagi keperluan manusia sama ada berbentuk pencapaian kendiri, keselesaan, pemilikan harta, kehormatan atau kemuliaan. Islam membenarkan manusia memenuhi keperluan tahsiniyyah tersebut jika ia berteraskam batasan akhlak dan tidak keterlaluan serta melampaui batas (mahāsin al-'adah). Dalam ertikata lain, keperluan sebagai khalifah di atas muka bumi hendaklah dipenuhi selari dengan penunaian tanggungjawab khusus sebagai hamba Allah SWT yang akan dipertanggungjawabkan semula segala amal dan tingkah lakunya di akhirat kelak. Adalah diharapkan pembangunan keusahawanan dapat bergerak seiring dengan objektif-objektif

17 Muḥammad al-Mubārak, Niz̄ām al-Islāmī al-Iqtiṣā Mabāḍ̂̄ wa Qawā 'id 'Ammah. (Beirūt: Dār al-Fikr, 1974). 
tersebut. Kemajuan tanpa kehidupan beragama dikhuatiri akan menempah kehancuran dan kemusnahan. ${ }^{18}$

Muhammad Farūq al-Nabhān mengatakan bahawa pembangunan ekonomi dalam Islam didominasi oleh tiga faktor utama iaitu akidah, Syariat dan akhlak. ${ }^{19}$ Daripada ketiga-tiga teras ini, lahir nilai-nilai seperti rabbaniyyah, insaniyyah, akhlāqiyyah dan wasatiyyah ${ }^{20}$ yang bukan sahaja membataskan tujuan ekonomi, malah turut mendorong segala urusan manusia berdasarkan tasawwur Islam. Pembentukan nilai-nilai akhlak Islam adalah manifestasi daripada semangat falsafah tauhid bagi memandu personaliti dan tingkah laku manusia melalui sistem Syariah yang telah ditetapkan oleh Allah SWT untuk kehidupan hamba-hambaNya.

Memandangkan ekonomi Islam adalah ekonomi berakhlak, maka penyempurnaannya dalam seluruh urusan kehidupan merupakan prasyarat utama untuk menjamin kecemerlangan pencapaian. Ini kerana, akhlak yang baik akan mendorong manusia lebih bertanggungjawab dalam menunaikan amanah dan kewajipan yang besar terhadap Allah SWT, pekerjaan, masyarakat dan diri sendiri. 'Abd Allāh 'Abd al-Muhsīn al-Ṭarīqī mengatakan akhlak berperanan mewujudkan suasana kesucian, keharmonian dan kasih sayang

18 Surah Ṭahā (20):124 yang bermaksud: “Dan sesiapa yang berpaling ingkar dari ingatan dan petunjukKu, maka sesungguhnya adalah baginya kehidupan yang sempit, dan Kami akan himpunkan dia pada hari kiamat dalam keadaan buta".

19 Muhammad Farūq al-Nabhān, Abhāth fì al-Iqtiṣāẹ al-Islām (Beirūt: Muassasah al-Risālah, 1986).

20 Nilai rabbaniyyah akan menghasilkan seluruh kegiatan ekonomi berlandaskan dasar-dasar serta matlamat ketuhanan dengan mengelak mencari rezeki dari sumber yang haram atau mengembangkan serta menggunakan semula hasil pendapatan tersebut dengan cara yang haram. Nilai insaniyyah adalah manifestasi perlaksanaan nilai ketuhanan yang memuliakan manusia sebagai khalifah di muka bumi. Justeru, pengabdian diri kepada Allah SWT merupakan bahagian paling asas dalam fitrah kejadian manusia melalui penghayatan ajaran-ajaran ketuhanan itu dalam konteks kehidupan seharian. Penghayatan tersebut memerlukan pemindahan dari konteks teori kepada praktikal sehingga dia mampu menjalankan kewajipannya terhadap Allah SWT, diri, keluarga, manusia dan alam keseluruhannya. Manakala nilai akhlāqiyyah menetapkan kesepaduan antara ekonomi dan akhlak dalam seluruh kegiatan ekonomi bermula daripada pengumpulan, pengeluaran dan pengedaran sehingga kepada penggunaan. Kemuncaknya nilai wasațiyyah yang bertindak sebagai jiwa sistem ekonomi Islam. Meskipun ia tidak nampak atau dirasakan tetapi padanya terletak rahsia keistimewaan dan kemuliaan diri manusia. Mengorbankan nilai-nilai keutamaan yang diseru oleh agama tidak dibenarkan sama sekali oleh Islam dalam seluruh aktiviti kehidupan manusia. Rujuk Yusūf al-Qaraḍāwī, Dawr al-Qiyām wa al-Akhlāq fì al-Iqtișād al-Islāmī, (2001), 27-81. 
dalam hubungan antara penjual dan pembeli. ${ }^{21}$ Dalam konteks ini, usahawan Muslim yang mengutamakan nilai-nilai akhlak seharusnya mengelak daripada menjual perkara-perkara yang diharamkan, menyorok barang, ${ }^{22}$ menghapuskan keluaranyang berlebihan agar harga tidak jatuh, ${ }^{23}$ membeli atau menjual barangan curi dan mengelak daripada bersumpah ketika berniaga. ${ }^{24}$

Ketika menghuraikan kaitan konsep akhlak dengan pembangunan ekonomi dalam Islam, Yūsuf al-Qaraḍāwī mengatakan bahawa adalah haram membenarkan pengedaran arak, kelab-kelab tarian dan aktiviti maksiat lain sebagai galakkan kepada aktiviti perlancongan dan mendapatkan matawang asing. Beliau berhujah berdasarkanpengharaman perlaksanaan ibadat haji ke atas golongan Musyrikin selepas tahun ke 9 Hijrah. Mereka yang berkunjung ke Masjid al-Haram ketika itu telah melakukan amalan-amalan tradisi yang pelik serta bertawaf mengelilingi Ka'bah dalam keadaan bertelanjang dengan alasan baju yang dipakai setiap hari telah dilumuri maksiat yang mengotorkan badan mereka. ${ }^{25}$ Larangan tersebut menyebabkan puluhan ribu orang Musyrikin tidak dapat melaksanakan ibadat tersebut dan secara tidak langsung ia merupakan satu kerugian ekonomi yang besar bagi kaum Muslimin. Namun,

21 'Abd Allah 'Abd al-Muḥ̣ịn al-Ṭārīqīi, al-Iqtisāẹ al-Islāmī Asūsun wa Mabādi'wa Aḥdāf (Riyadh: Muassasah al-Jārīsi Liltawzī', 1417H).

22 Surah Āli-'Imrān (3):180 yang bermaksud: "Dan jangan sekali-kali orang-orang yang bakhil dengan harta benda yang telah dikurniakan Allah kepada mereka darikemurahanNya menyangka bahawa keadaan bakhilnya itu baik bagi mereka, bahkan ia adalah buruk bagi mereka".

23 Surah al-Baqarah (2): 205 yang bermaksud: "Kemudian apabila ia pergi (dengan mendapat hajatnya), berusahalah ia di bumi, untuk melakukan bencana padanya, dan membinasakan tanaman-tanaman dan keturunan (binatang ternak dan manusia; sedang Allah tidak suka kepada bencana kerosakan".

24 Surah al-Mā’idah (5): 89 yang bermaksud: "Dan jagalah-peliharalah sumpah kamu". Manakala Nabi SAW bersabda yang bermaksud: "Sumpah itu melariskan barang dagangan tetapi menghapuskan keberkatannya". Lihat, al-Bukhārī, Abī "Abd Allāh bin Ismā'il bin Ibrāhim bin al-Mughīrah bin Bardizbah, Șaḥịh alBukhārī, Kitāb al-Buyū', Bāb Yamhaq Allāh al-Ribā wa Yarbì al-Sadaqāt, vol. 2, (t.t.), 8-9.

25 Yūsuf al-Qaraḍāwī, Dawr al-Qiyām wa al-Akhlāq fĭ al-Iqtiṣād al-Islāmī, (2001), 58. 
orang Islam telah diperingatkan supaya bersabar menanggung risiko tersebut demi mencapai kesempurnaan iman. ${ }^{26}$

Keutamaan hal ini turut ditekankan oleh Imam al-Bukhārī di mana sebelum membawa hadis-hadis mengenai kelebihan bekerja sendiri, beliau terlebih dahulu membahaskan persoalan halal dan haram serta syubhah yang perlu dielakkan oleh individu yang terlibat dalam perniagaan. ${ }^{27}$ Selari dengan itu juga, Ibn Hajar (1989) menyatakan bahawa seolah-olah Imam al-Bukhārī ingin mengisyaratkan bahawa walaupun perniagaan adalah satu perbuatan yang terpuji dari sudut kedudukannya sebagai mata pencarian yang halal, namun adakalanya ia boleh bertukar menjadi tercela. Contohnya, apabila aktiviti ini mendahului dari sesuatu yang seharusnya lebih utama daripadanya. Beliau berhujah berdasarkan hadis riwayat Jābir RA di mana para sahabat telah bangun meninggalkan Nabi SAW ketika Baginda SAW sedang berkhutbah selepas mereka melihat kedatangan satu kafilah dagang dari Syam dengan membawa makanan sehingga yang terus kekal bersama Nabi ketika itu hanya sekitar 12 orang. Tindakan mereka ini telah mendapat teguran daripada Allah SWT melalui firmanNya: ${ }^{28}$

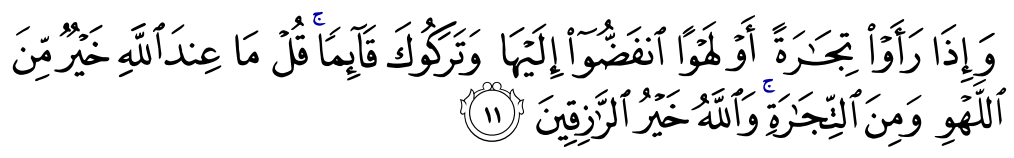

"Dan apabila mereka mengetahui kedatangan barang-barang dagangan (yang baharu tiba) atau (mendengar) sesuatu hiburan, mereka bersurai (lalu pergi) kepadanya dengan meninggalkan engkau berdiri (di atas mimbar-berkhutbah). Katakanlah (wahai Muhammad: pahala-balasan) yang ada di sisi Allah, lebih baik dari hiburan dan barang-barang dagangan itu; dan Allah sebaikbaik pemberi rezeki..."

(Surah al-Jumu'ah, 62: 11)

\footnotetext{
26 Surah al-Tawbah (9): 28 yang bermaksud: "Wahai orang-orang yang beriman! Sesungguhnya (kepercayaan) orang-orang kafir musyrik itu najis, oleh itu janganlah mereka menghampiri Masjid al-Haram sesudah tahun ini; dan jika kamu bimbangkan kepapaan, maka Allah akan memberi kekayaan kepada kamu dari limpah kurniaNya, jika Dia kehendaki. Sesungguhnya Allah Maha Mengetahui, lagi Maha Bijaksana".

27 Abī 'Abd Allāh Muhammad bin Ismā'il al-Bukhārī, Șah̄ịh al-Bukhārī, Kitāa al$B u y \bar{u}$ ', vol. 2 (Matba'ah Dār Ihyyā' al-Kitāb al-'Arabiyyah, t.t.).

28 Aḥmad bin 'Alī bin Hajār al-'Asqalānī, Bulūgh al-Marām min Adillah al-Ahkām, (Beirūt: Dār al-J̄̄l,1989), 372.
} 
Dalam hal ini, Imam al-Ghazālī telah memperincikan kepada tujuh perkara sebagai syarat untuk menyempurnakan kasih sayang seorang usahawan kepada agamanya. Syarat-syarat tersebut ialah mengelokkan niat dan akidah pada permulaan, berkeinginan untuk menegakkan salah satu daripada kewajipan fardhu kifayah dan membela kepentingan agama, tidak menghalang pasar akhirat oleh pasar dunia, sentiasa mengingati Allah SWT, berpuashati dan tidak terlalu tamak, menjauhkan diri dari perkara dan tempat yang syubhah dan haram serta sentiasa bermuhasabah diri kerana Allah SWT dan sentiasa mengawasi segala aktiviti muamalatnya. ${ }^{29}$

Lanjutan itu, walaupun kebanyakan ahli ekonomi konvensional berpendapat persoalan akhlak adalah masalah peribadi yang tiada kaitan dengan prestasi ekonomi sesebuah masyarakat atau negara, namun umat Islam seharusnya mengiktiraf bahawa sedikit sebanyak kegawatan ekonomi yang berlaku memang ada kaitannya dengan tingkahlaku manusia. ${ }^{30}$ Firman Allah SWT:

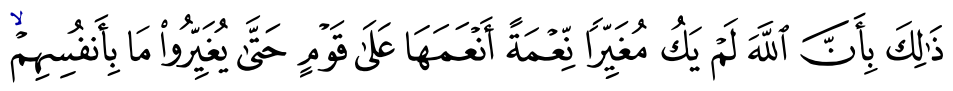

"(Balasan) yang demikian itu, ialah kerana sesungguhnya Allah tidak akan mengubah sesuatu nikmat yang telah dikurniakanNya kepada sesuatu kaum sehingga mereka mengubah apa yang ada pada diri mereka sendiri"

(Surah al-Anfāl, 8: 53)

Sayyid Quṭ menjelaskan ayat ini adalah gambaran keadilan Allah SWT dalam melayani hamba-hambaNya. Segala nikmat yang telah dikurniakan tidak akan dirampas kembali kecuali sesudah hambaNya mengubah niat, tingkahlaku dan kedudukan mereka. Tindakan tersebut mewajarkan Allah SWT bertindak mengubah nikmat yang juga merupakan sebagai ujian kerana mereka tidak bersyukur kepada Allah SWT dan memuliakan nikmat tersebut. ${ }^{31}$

\footnotetext{
29 Abū Ḥāmid Muḥammad bin Muḥammad al-Ghazālī, Ihyā' 'Ulūm al-Dīn (Beirūt: Dār al-Kutub al-'Ilmiyyah, vol. 2, 1996), 94-99.

30 Haron Din, 'Kegawatan Ekonomi Sekarang Hubungkaitnya dengan Amalan Bisnes dan Sistem Ekonomi Yang Diamalkan,' dalam Islam dan Bisnes, ed. Abd Jalal Basimi, vol. 1 (Johor Bahru: Perbadanan Johor, 1999).

31 Sayyid Qutb, F̄̄ Zilal al-Qur'an, vol. 3 (Beirūt: Dār al-Shurūq, 1992).
} 


\section{METODOLOGI}

Artikel ini akan menganalisis elemen akhlak sebagai salah satu komponen utama dalam pembentukan personaliti usahawan Islam. Huraian persoalan teoretikal gagasan tersebut adalah berasaskan analisis kandungan (content analysis) berasaskan piawaian yang telah ditetapkan oleh al-Quran dan Hadith serta pandangan intelektual Islam supaya kerangka pemikiran tersebut selari dengan tasawwur Islam.

\section{ANALISIS}

Oleh kerana sistem perekonomian Islam adalah berteraskan berakhlak, maka tidak mungkin aktiviti keusahawanan Islam dapat dipisahkan daripada nilai-nilai akhlak. Selain itu, akhlak juga memiliki rahsia keistimewaan dan kemuliaan yang bertindak sebagai mekanisme menguatkan hubungan antara kehidupan manusia dengan jiwa sistem ekonomi Islam. ${ }^{32}$ Elemen tersebut adalah selari dengan konsep ganjaran dalam Islam iaitu memperolehi pendapatan dengan cara yang tidak dilarang, bekerja kuat dan ikhlas, pendapatan yang diperolehi secara sah adalah amanah dari Allah SWT, manakala pendapatan dengan cara yang tidak sah akan mendapat kutukan daripadaNya. Konsep ini adalah jauh berbeza daripada konsep sekular yang menganggap bahawa pemikiran dan tingkah laku manusia adalah asas yang menentukan nilai dan dasar hidup manusia.

\section{KEUTAMAAN DALAM PEMBANGUNAN PERSONALITI USAHAWAN}

Memandangkan tasawwur Islam bersifat ilmiah, manakala asas bekerja adalah untuk mendapatkan kesejahteraan dan kebahagiaan di dunia dan akhirat, maka budaya kerja Islam juga perlu difahami dan diamalkan berdasarkan ilmu yang ditafsirkan dengan cara yang sewajarnya. Keterbatasan kapasiti keupayaan akal dan kebebasan manusia untuk menggunakannya ${ }^{33}$ menyebabkan ia perlu diberi panduan, tunjuk ajar dan bimbingan supaya akal dapat berfungsi dengan baik sejajar dengan tujuan asal ia diciptakan oleh Allah SWT dalam usaha manusia menguruskan urusan agama dan keduniaannya. Semua ini mesti

32 Yūsuf al-Qaraḍāwī, Dawr al-Qiyām wa al-Akhlāq fì al-Iqtiṣād al-Islāmī, 2001), 81.

33 Syed Muhammad Naquib al-Attas, 'The Nature of Man and the Psychology of the Human Soul,' dalam Psychology of Personality, Islamic Perspective, ed. Amber Haque dan Yasien Mohamed (Singapura: Cengage-Learning Asia Pte Ltd., 2009), 131. 
merujuk kepada asas utama pemikiran epistemologi Islam yang terkandung dalam al-Quran dan hadis serta dijelaskan secara praktikal oleh para sahabat dan al-salaf al-ṣālih.

Dari sudut pandangan teologi Islam, tabiat manusia adalah ditentukan oleh sikap mereka. ${ }^{34}$ Secara umumnya, elemen utama kejadian manusia ialah aljism dan al-nafs. Manakala keperluan asas mereka adalah berlandaskan kepada asal kejadiannya yang meliputi al-nafs, al-'aql,al-qalb, al-rūh dan al-fitrah. Masing-masing mempunyai daya (quwwah) tersendiri kecuali al-jism yang hanya memiliki daya menterjemahkan atau menzahirkan perintah al-nafs. ${ }^{35}$ Feryad Hussain menjelaskan pembangunan personaliti yang baik berlaku apabila wujud keseimbangan antara enam konsep asas iaitu insāniyyah, rū $h$, qalb, dhikr (mengingati Allah SWT, kesedaran, beriman dan komitmen), 'aql (pemikiran, refleksi, intelektual dan kognitif) dan fiqh/' ilm (ilmu yang benar). ${ }^{36}$ Syed Muhammad Naquib al-Attas pula merumuskan, terminologi qalb, nafs, $r \bar{u} h$ dan 'aql adalah berhubungkait dengan kerohanian. Elemen-elemen tersebut merujuk kepada kebendaan atau fizikal manusia serta bukan kebendaan atau spiritual. Taraf manusia sebagai sebaik-baik kejadian akan menjadi lebih rendah daripada binatang tanpa keimanan yang sebenar dan kerja-kerja yang baik. $^{37}$

Lanjutan itu, pembentukan konsep pembangunan keusahawanan berdasarkan tasawwur Islam seharusnya meraikan keperluan kerohanian dan material manusia secara seimbang. Konsep ini sudah semestinya adalah

34 Surah al-Ra'd (13): 11 yang bermaksud: "Sesungguhnya Allah tidak mengubah apa yang ada pada sesuatu kaum sehingga mereka mengubah apa yang ada pada diri mereka sendiri."

35 Pelbagai dimensi jiwa manusia juga memiliki kepelbagaian sifat dan keperluan dasar. Al-Jism bersifat fizikal yang memerlukan biologi. Al-Nafs bersifat kehidupan kerana dengan nafsu manusia mempertahankan dan melanjutkan kehidupannya, memerlukan ketenteraman dan keamanan. $A l$ - 'Aql bersifat pemikiran dan rasional memerlukan penghargaan kendiri. Al-Qalb bersifat supra-rasional, perasaan dan emosional yang memerlukan cinta dan kasih sayang. Al-Rüh bersifat spiritual yang memerlukan dasar kewujudan diri atau aktualisasi diri (manusia sebagai khalifah) manakala al-fitrah bersifat suci dan memerlukan dasar kepada agama. Oleh itu, manusia perlu memenuhi keperluan bersifat jismiyyah, nafsiyyah dan rūhaniyyah (spiritual). Lihat, Baharuddin, Paradigma Psikologi Islami, Studi Tentang Elemen Psikologi dalam al-Quran (Yogyakarta: Pustaka Pelajar, 2004), 240-243.

36 Feryad Hussain, 'Reflections on One Model of Islamic Psychology and the Impact of Implementation on Iman,' The Islamic Quarterly, 51/1 (2007): 83.

37 Syed Muhammad Naquib al-Attas, 'The Nature of Man and the Psychology of the Human Soul,' 133. 
berbeza dengan ciri-ciri personaliti usahawan berdasarkan perspektif Barat meskipun ia dikatakan bersifat universal dengan merentasi sempadan bangsa, geografi dan masa.Sebagai penganut sebuah agama yang syumul, tidak sukar bagi umat Islam untuk mencari model atau formula yang perlu dicontohi kerana kerangkanya telah sedia ada di hadapan merekaberdasarkan firman Allah SWT:

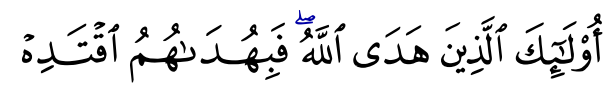

"Mereka (nabi-nabi) itulah, orang-orang yang telah diberi petunjuk oleh Allah, maka turutlah olehmu (wahai Muhammad) akan petunjuk mereka."

(Surah al-An'ām, 6: 90)

Muhammad 'Awāḍ al-Huzaymah et al. menjelaskan konsep hubungan manusia dengan Allah SWT adalah dalam bentuk 'Ubūdiyyah, manakala hubungan dengan para nabi dan rasul adalah dengan mengambil teladan dan petunjuk. ${ }^{38}$ Meskipun aktiviti para nabi, sahabat dan orang-orang soleh dalam bidang pekerjaan adalah pelbagai bentuk tetapi para ulama berijmak pada tuntutan mencari keperluan hidup melalui jalan yang yang dibenarkan oleh Syarak sahaja.

Justeru, keusahawanan Islam amat mementingkanprinsipkeadilan dan kebebasan serta menolak sebarang unsur paksaan atau kezaliman terhadap kedua-dua belah pihak. Antaranya, mengutamakan konsep persetujuan bersama (sifat redha-meredhai), ${ }^{39}$ melaksanakan kontrak atau menunaikan janji, ${ }^{40}$ pengukuran, timbangan serta sukatan yang sempurna, ${ }^{41}$ kejujuran dan perlindungan. Dalam erti kata lain, prinsip Islam tidak menganggap kehidupan ini sebagai satu perlumbaan, tetapi perlu kepada konsep saling tolong-

38 Muḥammad 'Awad al-Huzaymah et al., al-Nuzūm al-Islāmiyyah (Jordan: Dār al'Umar, 1991), 33.

39 Sabda Nabi SAW yang bermaksud: "Tidak akan berpisah antara penjual dan pembeli sehingga redha-meredhai antara kedua-duanya”. Lihat, al-Tirmīdhī, Abī 'Isā Muhammad bin 'Isā bin Sūrah, al-Jamī' al-Ṣāhīh, Sunan al-Tirmīdhī, Kitāb

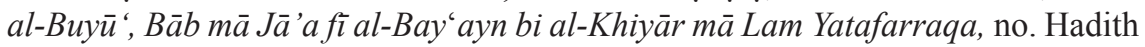
1248, vol. 35 (Beirūt: Dār Kutub al-'Alamiyyah, 1987), 551.

40 Surah al-Mā'idah (5): 1 yang bermaksud: "Wahai orang-orang yang beriman!, penuhilah serta sempurnakanlah perjanjian-perjanjian".

41 Surah al-Isrā' (17): 35 yang bermaksud: "Dan sempurnakanlah sukatan apabila kamu menyukat dan timbanglah dengan timbangan yang adil. Yang demikian itu baik (kesannya bagi kamu di dunia) dan sebaik-baik kesudahan (yang mendatangkan pahala di akhirat kelak". 
menolong yang dibina dalam bentuk semangat perhubungan dan kerjasama ekonomi. Sistem ekonomi Islam menolak dengan kerasnya pendekatan hidup sistem sekular seperti falsafah "struggle for existance", sebaliknya menyarankan kepada "cooperation for existance" sebagai etika hidup yang bersesuaian dengan falsafah tauhid..$^{42}$

Atas dasar itu juga, para usahawan perlu berpegang kepada empat prinsip asas pengeluaran berteraskan Islam iaitu, mengetahui pandangan manusia terhadap manusia dan alam, meningkatkan daya pengeluaran dalam lingkungan etika Islam, membasmi pembaziran sumber-sumber alam kerana malas serta menggunakan pendekatan ajaran dan Syariah Islam. ${ }^{43}$ Manakala Isma'il Raji al-Faruqi menjelaskan bahawa operasi keusahawanan perlu berasaskan empat prinsip yang mempengaruhi proses pengeluaran iaitu pertama, Syariah tidak membenarkan pengeluaran hasil atas dasar keuntungan semata-mata, sebaliknya lebih menggalakkan penyediaaan barangan atau perkhidmatan yang bermanfaat kepada orang ramai. Kedua, barangan yang diharamkan oleh Syarak tidak boleh dihasilkan kecuali apabila ia amat diperlukan. Ketiga, apa yang dihasilkan mestilah dipersembahkan dengan sebenar-benarnya. Pembungkusan sebagai seni memperdayakan adalah tidak dibenarkan. Keempat, pegangan akidah adalah asas yang mendorong kepada pengeluar untuk menyedari dan mengamalkan kebenaran bukan kerana takut terhadap hukuman yang akan diterima daripada kerajaan. ${ }^{44}$

Generasi umat terbaik Islam sepanjang zaman sebelum ini ${ }^{45}$ telah membuktikan bahawa mereka berjaya dalam keusahawanan melalui kaedah perlaksanaannya secara holistik berteraskan asas-asas Islam yang syumul. Dalam hal ini, Imam Malik juga telah mengingatkan bahawa urusan sesuatu umat tidak akan menjadi baik melainkan dengan apa yang telah menjadikan

42 Nik Mustapha Nik Hassan, 'Pendekatan Sistem Ekonomi Islam dalam Meningkatkan dan Memajukan Kedudukan Ekonomi Masyarakat Melayu,' Occasional Paper Kulliyah of Economics, International Islamic University, 1, (1989): 4.

43 Monzer Kahf, The Islamic Economy (Indiana: The Muslim Students' Association of the United State, 1978).

44 Isma'il Raji al-Faruqi, al-Tawhid: Its Implications for Thought and Life (Virginia, U.S.A.: International Institute of Islamic Thought, 1992), 178.

45 Sabda Nabi SAW yang bermaksud: "Sebaik-baik manusia ialah yang berada pada kurunku, kemudian mereka yang selepas kurun tersebut dan kemudian mereka yang mengiringi kurun selepas itu... ". Lihat, Imām al-Bukhārī, Șāḥ̄ḥ al-Bukhārī, Kitāb al-Shahādah, Bāb Lā Yashhad 'alā Shahādah Jawr Idhā Ashhād, no. Hadith 2651, (2000), 209. 
baik bagi umat yang terlebih awal. ${ }^{46}$ Maka sebaik-baiknya, panduan dan model pembangunan usahawan Muslim dewasa ini haruslah datang daripada masyarakat awal Islam tersebut. Malangnya para cendekiawan dan intelek Islam masa kini kurang mengetengahkan konseptual keusahawanan Islam seiring dengan perkara-perkara yang berkaitan dengan akidah, Syariah dan akhlak kepada masyarakat.

\section{RUMUSAN}

Secara umumnya, matlamat pembangunan ekonomi telah dimanifestasikan dalam al-Quran secara jelas apabila terminologi "rizq" dan pecahannya telah diulang lebih dari seratus dua puluh kali dengan hampir keseluruhannya menyandarkan kepada Allah SWT sebagai "al-Razzāq". Kekerapan pengulangan dan sandaran yang konsisten ini adalah sebagai peringatan kepada manusia supaya sentiasa mengambil iktibar bahawa perkara yang menjadi asas dalam kehidupan mereka mempunyai pertalian yang rapat dengan Pencipta alam ini. Peringatan tersebut adalah selari dengan Maqāsìid al-Syarī'ah yang menetapkan bahawa matlamat pembangunan ekonomi dalam Islam lebih menekankan kepada konsep kesejahteraan hidup manusia (alfalah), kehidupan yang baik (hayāt tayyibah), mementingkan persaudaraan (ukhuwwah) dan keadilan sosio-ekonomi ('adālah) serta kepuasan yang seimbang ( qanā'ah) dalam dimensi kebendaan dan kerohanian. Maka, syarat

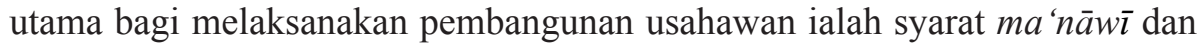
bukannya $m \bar{a} d \bar{l}$, tetapi kedua-duanya perlu bergerak secara bersepadu dalam segenap aspek. Dengan ini, keutamaan akhlak dalam sistem ekonomi Islam yang bersifat syumul mampu melahirkan perubahan secara menyeluruh dan konsisten dalam bidang keusahawanan. Berbakti kepada manusia dengan menawarkan perkhidmatan atau barangan bagi memenuhi keperluan mereka bukan penghujung segala-galanya kepada usahawan Islam. Sebagai sistem yang berpaksikan kepada akidah, Syariah dan akhlak, ukuran mutlak kejayaan usahawan tidak terbatas kepada tahap kepuasan diri dan pelanggan sematamata, tetapi turut merangkumi keredaan Allah SWT terhadap setiap pekerjaan yang dilakukan.

\section{RUJUKAN}

'Abd Allāh 'Abd al-Muhsīn al-Ṭārīqī, al-Iqtiṣād al-Islāmī Asūsun wa Mabādī' wa Ahdāf (Riyāḍ: Muassasah al-Jarīṣì li al-Tawzi‘, 1417H).

46 Abū al-Hassan 'Alī al-Nadw̄î, al-Arkān al-Arba' ah fì Daw' al-Kitāb wa al-Sunnah (Kuwait: Dār al-Qalam,1978). 
Afzalur Rahman, Subject Index of Quran (Lahore: Islamic Publications, 1983).

Abī 'Abd Allāh Muhammad bin Ismā'̄̄l al-Bukhārī, Șāḥ̄ḥ al-Bukhārī, Kitāb al-Buyū', vol. 2 (Matba'ah Dār Ihyā’’ al-Kitāb al-'Arabiyyah, t.t.).

Abū al-Hassan 'Alī al-Nadwī, al-Arkān al-Arba 'ah fì Daw' al-Kitāb wa alSunnah (Kuwait: Dār al-Qalam, 1978).

Baharuddin, Paradigma Psikologi Islami, Studi Tentang Elemen Psikologi dalam al-Quran (Yogyakarta: Pustaka Pelajar, 2004).

Feryad Hussain, 'Reflections on One Model of Islamic Psychology and the Impact of Implementation on Iman', The Islamic Quarterly, vol. 51/1 (2007): 78-92.

al-Ghazālī, Abū Hamīd Muhammad bin Muhammad, Ihyā' 'Ulūm al-Dīn, (Beirūt: Dār al-Kutub al-'Ilmiyyah, 1996).

Haron Din, 'Kegawatan Ekonomi Sekarang Hubungkaitnya dengan Amalan Bisnes dan Sistem Ekonomi Yang Diamalkan', dalam Islam dan Bisnes, ed. Abd Jalal Basimi, vol. 1 (Johor Bahru: Perbadanan Johor, 1999).

Ibn Hajar al-'Asqalān̄̄, Bulūgh al-Marām min Adillah al-Ahkām (Beirūt: Dār al-J̄̄l, 1982).

Ibn Khaldūn, Muqaddimah (Qāhirah: Dār al-Sha'b, t.t.).

Isma'il Raji al-Faruqi, al-Tawhid: Its Implications for Thought and Life (Virginia, U.S.A.: International Institute of Islamic Thought, 1992).

Monzer Kahf, The Islamic Economy (Indiana: The Muslim Students' Association of the United State, 1978).

Muhammad 'Abd al-Halīm 'Amr, 'Mafhūm al-Intāj wa Darūrāth wa Ahdāfīh', Majallah Markāz Ṣāliḥ Kamīl li al-Iqtiṣād al-Islāmī Jāmi 'ah al-Azhār, 3/8 (1999): 90-91.

Muḥammad 'Awāḍ al-Huzaymah, al-Nuẓūm al-Islāmiyyah (Jordan: Dār al'Umar, 1991).

Muhammad Faruq al-Nabhan, Abhath fì al-Iqtiṣād al-Islām (Beirūt: Muassasah al-Risālah 1986).

Muhammad al-Mubārak, Niẓām al-Islāmī al-Iqtiṣā Mabād̄̄ wa Qawāìd 'Ammah (Beirūt: Dār al-Fikr, 1974).

Muhammad Nejatullah Siddiqi, The Economic Enterprise in Islam (Lahore Islamic Publications Ltd., 2000).

Mustaq Ahmad, Business Ethics in Islam (Islamabad: International Institute of Islamic Thought, 1995). 
Nik Mustapha Nik Hassan, 'Pendekatan Sistem Ekonomi Islam dalam Meningkatkan dan Memajukan Kedudukan Ekonomi Masyarakat Melayu', Occasional Paper Kulliyah of Economics, International Islamic University, 1 (1989).

Syed Muhammad Naquib al-Attas, 'The Nature of Man and the Psychology of the Human Soul', dalam Psychology of Personality, Islamic Perspective, ed. Amber Haque dan Yasien Mohamed (Singapura: Cengage-Learning Asia Pte Ltd., 2009).

Sayyid Quṭb, Fī Zilāl al-Qurān, vol. 3 (Beirūt: Dār al-Shurūq, 1992).

Sayyid Sābiq, Fiqh al-Sunnah, vol. 3 (Qāhirah: Dār al-Fath li al-I‘lam al'Arabī, 1994).

al-Tirmīdhī, Abī 'Isā Muḥammad bin 'Isā bin Sūrah, al-Jamī' al-Ṣaḥ̄h, Sunan al-Tïmīdhī, vol. 3 (Beirūt: Dār Kutub al-‘Alamiyyah, 1987).

Yūsuf al-Qarāọāwī, Dawr al-Qiyām wa al-Akhlāq fì al-Iqtiṣād al-Islāmī, vol. 2 (Qāhirah: Maktabah Wahbah, 2001). 